\title{
Chia (Salvia hispanica L.) - A Potential Crop for Food and Nutrition Security in Africa
}

\author{
Pauline Ikumi ${ }^{1}$, Monica Mburu $^{1} \&$ Daniel Njoroge ${ }^{1}$ \\ ${ }^{1}$ Institute of Food Bioresources Technology, Dedan Kimathi University of Technology, Private Bag. Dedan \\ Kimathi, Nyeri, Kenya \\ Correspondence: Monica Mburu, Institute of Food Bioresources Technology, Dedan Kimathi University of \\ Technology, Private Bag. Dedan Kimathi, Nyeri, Kenya. E-mail: monimbu8@ gmail.com
}

Received: October 1, 2019

Accepted: October 19, 2019

Online Published: October 30, 2019

doi:10.5539/jfr.v8n6p104

URL: https://doi.org/10.5539/jfr.v8n6p104

\begin{abstract}
There has been an increasing demand for functional foods with numerous health benefits due to intensified consumer awareness leading to a major shift in the consumption patterns of food. This has largely been attributed to increased lifestyle diseases across different populations. The use of food with nutraceutical and functional properties for management of lifestyle diseases like diabetes, obesity, and cardiovascular problems is now gaining momentum among the public. Consequently, the consumption of chia seeds (Salvia hispanica L.) has increased in recent years particularly due to its high content of omega- 3 fatty acids and dietary fiber. Chia seeds also contain high quality proteins which offer all the essential amino acids and several vital minerals. In addition, chia seeds are a potential source of antioxidants and polyphenolic compounds such as chlorogenic acid, caffeic acid, myricetin, quercetin, and kaempferol with the major phenolic acid being rosmarinic. Owing to the rich nutritional profile, chia seeds provide numerous health benefits such as; cardiac protective and hepatic protective effects, anti-aging and anti-carcinogenic properties. The high amounts of dietary fibers present in the seeds also confer benefits by preserving good glycemic control thus helps in controlling diabetes mellitus. In addition to the numerous health benefits accrued to consumption of chia seeds, they have great potential in application in the food industry for; development of various baked products, production of biodegradable edible films, use as emulsifiers and stabilizers among other uses. This review provides an in-depth insight into the potential of chia crop in promoting nutrition and food security by providing comprehensive information pertaining to; its origin, cultivation and distribution, physical properties, nutritional characteristics, health benefits, functional properties and its potential use in the food industry. It evident that chia seeds contain superior nutritional components as compared to other seeds and also confers many health benefits such as antioxidative, anti-hypertensive and hypoglycemic properties among others. It possesses physical and functional properties that make it an excellent crop for use in food applications for the development of functional foods. Moreover, its application not only limited to food but can also be used for feed. Chia therefore demonstrates great potential as a crop that can be utilized for improved food and nutrition security.
\end{abstract}

Keywords: chia, food security, functional, nutritional

\section{Introduction}

Chia (Salvia hispanica L.) is classified as a herbaceous plant that belongs to the order- Lamiales, family -Lamiaceae, subfamily -Nepetoideae, and genus -Salvia (Cahill \& Provance, 2002; Artcos, 2018). Chia is reported to have originated from the low latitudes of Mexico and Guatemala, along with amaranthus, quinoa and maize and it was one of the four staple foods of Mayas and Aztech populations (Munoz, Cobos, Diaz, \& Aguilera, 2013). It is majorly cultivated for its seeds and yields white or purple blossoms. Chia can grow up to $1 \mathrm{~m}$ tall and has inversely orchestrated leaves, its flowers are little $(3-4 \mathrm{~mm})$ with little corollas and combined bloom parts that add to a high self-pollination rate. The seed shading and color differs from dark, grey, and dark-spotted to white, and the shape of the chia seed is semi-oval, with a length somewhere in the range of 1 and $2 \mathrm{~mm}$, a diameter somewhere in the range of 0.8 and 1.3 and a width somewhere in the range of 0.8 and $1.4 \mathrm{~mm}$ (Munoz, Cobos, Diaz, \& Aguilera, 2012; Cahill \& Provance, 2002).

Chia is a word that was obtained from a Spanish word meaning oily, thus, it is referred to as an oily seed packing a power house of omega 3 fatty acids. It is also rich in predominant quality protein, high degree of dietary fiber, 
minerals, vitamins, and a variety of polyphenolic antioxidants which work to protect the seed from microbial and chemical degradation (Cahill, 2003). The value of chia arises from is nutritional properties and medicinal use. The contents of chia seeds include polyunsaturated fatty acids, dietary fiber, vitamins, calcium, proteinincluding all essential amino acids and other vital minerals (Munoz et al., 2013; Ullah et al., 2016). After a long oblivion in recent years this crop has been rediscovered, nowadays it is cultivated as a seed crop and commercialized as a functional food and feed. Chia seeds are perhaps the most advantageous nourishment on earth, stuffed with supplements and medical advantages for human body and mind. Health benefits include nourishing the digestive system, promoting healthier skin, strong muscles and bones, lowers the risks of cardiovascular diseases, diabetes and aging signs (Ullah et al., 2016; Ali et al., 2012). Mature chia seeds contain mucilage in their epidermal cells thus, when the seed is placed in water, it raptures the primary cell layer that obtrudes from the epidermal cells developing a coating around the seed which surges in size and forms a gel-like appearance on chia (Muñoz et al., 2012). This gel characteristic being a natural phenomenon of a chia seed has great potential in the development of functional food products such as stabilizers, emulsifiers and thickeners (Coorey, Tjoe \& Jayasena, 2014). Moreover, over the years' special attention has been drawn to the use of chia as feed, for instance dairy industries have explored to improve the nutraceutical profile of milk by increasing the content of polyunsaturated fatty acids (PUFA) omega-3 FA (Dewhurst, Fisher \& Wilkins, 2006). The lipid profile in milk can be sharply modified by feeding animals with forages rich in omega-3 (Dewhurst, Shingfield, Lee \& Scollan, 2003) as well as by supplementing oilseeds or marine oils (Chilliard et al., 2001). Chia, therefore offers massive nutritional and therapeutic potential with a diverse future perspective for food, feed, pharmaceutical and nutraceutical sectors. Owing to its superior nutritional, functional and health benefits. The contents of this paper will provide a detailed analysis of chia as a crop that promotes nutrition and food security by accounting comprehensively on its origin, cultivation and distribution, physical properties, nutritional characteristics, health benefits, functional properties and its potential use in the food industry.

\section{Origin, Cultivation and Distribution of Chia}

Chia originated at the low latitudes of Mexico and Guatemala. Along with other crops such as amaranthus, quinoa and maize it was one of the four staple foods of Mayas and Aztech populations (Munoz et al., 2013). Surpassed only by maize and beans, the pre-Colombian society practiced chia cultivation as a main crop (Craig, 2004). Around, $3500 \mathrm{BC}$ chia seeds were used as human food, over the years from $1500 \mathrm{BC}$ to $900 \mathrm{BC}$, Central Mexico adopted chia as a staple food BC ( Cahill, 2003; Ayerza \& Coates, 2005). The seeds were used in the preparation of a variety of food, medicine etc. by the Mayas and Aztecs tribes. Nonetheless, there is evidence that suggests in 1531 there was cultivation of chia in the Southside of Sinaloa (Dubernard, 1991). There was however a decline of chia as a staple food in Mexico (1550-1810) after the Spanish colonization and during this period when its cultivation was prohibited the crop faced extinction. Following this duration where chia was at the verge of extinction, renaissance of chia as food in Mexico occurred between 1810 to 1990 after which it was integrated as a modern food in the world (1990-2010) (Anacleto et al., 2016). The incorporation of chia as a modern food was facilitated by the various studies on chia as a vegetal and crop source of PUFAs $\omega 3$, proteins and fiber (Weber, Gentry, Kolhepp, \& McCrohan, 1991) with chia currently being produced in over fourteen countries around the world ( Ayerza \& Coates, 2011; Coates \& Ayerza, 1996). From a nutritional point of view, while there exist several food sources to cover the requirement of PUFAs $\omega 3$ such as menhaden fish, salmon, algae and flax (Sapio, Bueno, Busilacchi \& Severin, 2008; Castro, 2002), none of them is safer, more sustainable and traceable than chia due to the fact that it is a unique source that can be directly consumed.

Literature suggests that a daily consumption ranging from 25-50 grams of seed per day is enough to cover the PUFAs $\omega 3$ requirements for adults (Souza, Souza, Santo \& Rosa, 2015; Vuksan et al., 2007). Over the last six years, the worldwide demand for chia has risen linearly and in 2014 Paraguay, Argentina, Mexico and Bolivia were identified as the four major producers of this oilseed (Peperkamp, 2015). Presently, the demand for chia as a food crop is growing with countries such as USA, Chile, Argentina and Italy where for their climatic conditions it has proven difficult to cultivate chia hence they are assessing various agronomic practices to acclimate it to their agricultural sectors (Kaiser \& Ernst, 2016; Amato et al., 2015; Bochicchio et al., 2015; Tello, 2014).

\section{Nutritional Properties of Chia}

Chia seed commercialization in Europe, United States and Canada has famed recent interests due to its nutritional properties. The European Council and the European Parliament has recently approved the use of chia seeds as a novel food ingredient in amounts not exceeding $10 \%$ in breakfast cereals, baked products, nut and seed mixes and fruits (Commission, 2013; Commission, 2009). The recommendation of chia seeds globally has been attributed to their high protein degree, dietary fiber, antioxidants, minerals and vitamins. However, their oil 
content having the largest fraction of $\alpha$-linolenic acid ( $\omega$-3) likened to other natural sources known to date is their nutritional breakthrough (Guiotto, Ixtaina, Tomás, \& Nolasco, 2013). The other parts of chia plant such as leaves and stems have shown to contain nutritive value especially the leaves which contain PUFA and other essential oils thus a good ruminant nutrition source (Peiretti \& Gai, 2009; Ahmed, Ting \& Scora, 1994). The seed composition has shown to vary from region to region depending on the conditions of where it grows. Although chia seeds have shown to thrive in tropical and subtropical areas, their cultivation can also be done in trivial climates (Ayerza, 2010). As a botanical source, chia seeds composition is expected to vary as a result of different growing location, years within a growing location due to environmental and genetic factors (Ayerza \& Coates, 2004). In spite of this, chia has been reported to be of great nutritional value and auspicious bioactive compounds for human health (Table 1).

Table 1. Nutritional composition of chia seeds from different regions

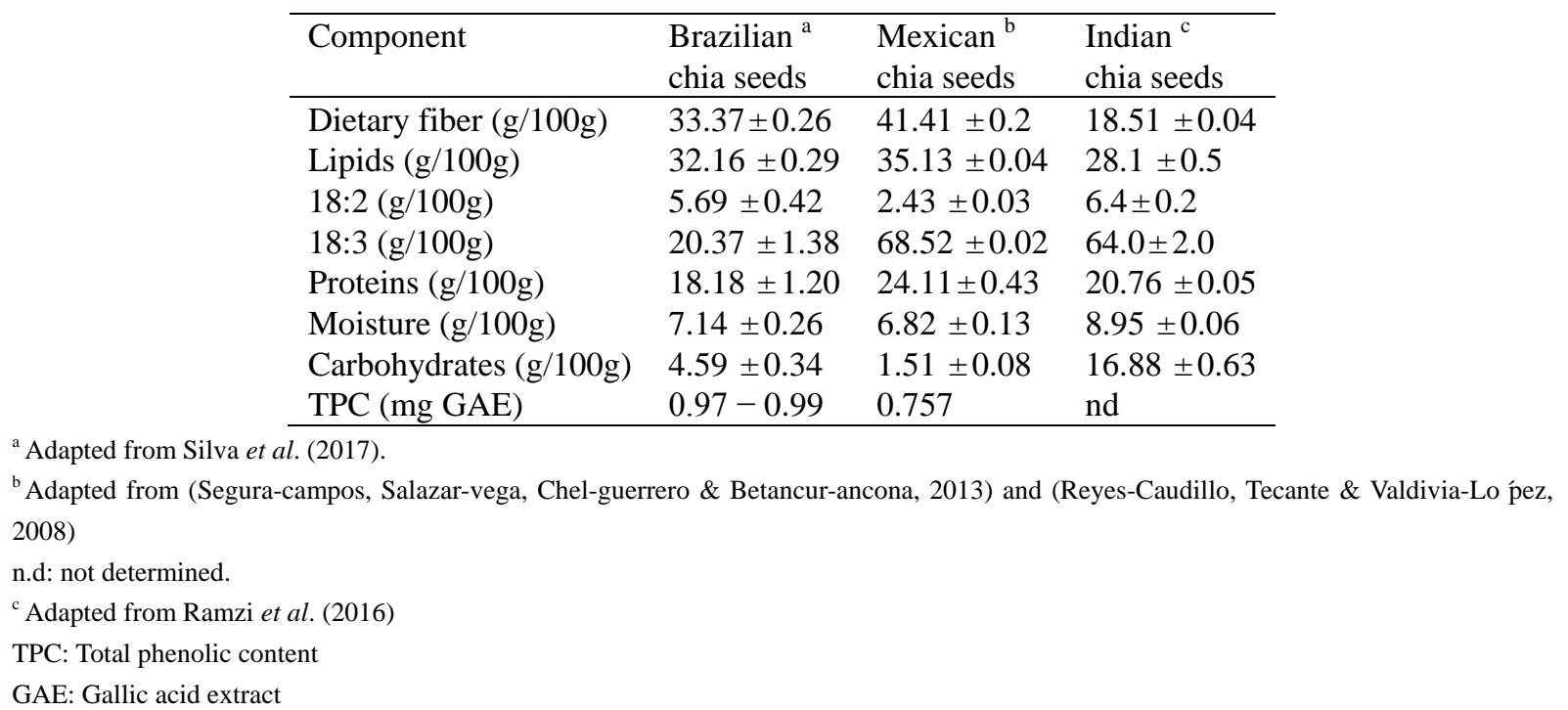

According to a report USDA, (2004) chia seeds contain approximately $34.40 \%$ total dietary fiber (TDF), $30.74 \%$ total lipids, $42.12 \%$ total carbohydrates, $5.80 \%$ moisture, high values $(335-860 \mathrm{mg} / 100 \mathrm{~g}$ ) of calcium, phosphorus and to a smaller extent sodium, iron, and zinc $(4.58-16 \mathrm{mg} / 100 \mathrm{~g})$. To add on that, niacin, vitamin C and A can be found substantially in chia seeds.

\subsection{Lipids}

Chia seeds comprise about $25-38 \%$ oil by weight, which makes them the richest botanical source of omega-3 $\alpha$-linolenic acid (C18:3, ALA, up to 68\%) of any identified vegetable source (Ayerza \& Coates 2011). It possesses high amounts of alpha-linolenic (omega-3 or n-3) (19.5\%) and alpha-linoleic acids (omega-6 or n-6) (5.2\%), all essential nutrients since they cannot be synthesized by the human body. As Ayerza, (1995) writes, fatty acids in chia oil are extremely unsaturated specifically linoleic (17-26\%) and linolenic (50-57\%) acids. The oil content and the amount of oleic, linoleic, and linolenic acids is influenced by the region of cultivation. For example, in terms of quality, variation in temperature levels has been ascribed as the key factor that affects oil composition (Velasco \& Fernandez-Martinez, 2002). Ayerza \& Coates, (2011) reported that oil content in relation to the weight of the chia seed disclosed no significant $(\mathrm{P}<0.05)$ differences among different locations. However, oil composition, measured as fatty acid percentages, were significantly $(\mathrm{P}<0.05)$ affected by location (Table 2)

Table 2. Mean values of protein content, oil content and fatty acid composition of chia grown in three ecosystems.

\begin{tabular}{|c|c|c|c|c|c|c|c|c|c|c|c|c|}
\hline Origin & Protein $^{a}$ & $(\%)^{\mathrm{b}, \mathrm{d}}$ & $\begin{array}{l}\text { Lipids } \\
(\%)^{\mathrm{b}}\end{array}$ & $\begin{array}{l}16: 0 \\
(\%)^{\mathrm{c}}\end{array}$ & $\begin{array}{l}18: 0 \\
(\%)^{\mathrm{c}}\end{array}$ & $\begin{array}{l}18: 1 \\
(\%)^{\mathrm{c}}\end{array}$ & $\begin{array}{l}18: 2 \\
(\%)^{\mathrm{c}}\end{array}$ & $\begin{array}{l}18: 3 \\
(\%)^{\mathrm{c}}\end{array}$ & $\begin{array}{l}\text { SAT } \\
(\%)^{\mathrm{c}}\end{array}$ & $\begin{array}{l}\text { PUFA } \\
(\%)^{\mathrm{c}}\end{array}$ & $\begin{array}{l}-6:-3 \\
\text { (ratio) }\end{array}$ & $\begin{array}{l}\text { PUFA: } \\
\text { SAT }\end{array}$ \\
\hline Argentina & $16.45 b$ & & $33.5 \mathrm{a}$ & $6.89 b$ & $2.36 \mathrm{a}$ & $6.73 b$ & $22.5 \mathrm{a}$ & $60.35 b$ & $9.26 \mathrm{~b}$ & $82.85 \mathrm{a}$ & $0.37 \mathrm{a}$ & $9.01 \mathrm{a}$ \\
\hline Bolivia & $26.03 \mathrm{a}$ & & $29.98 \mathrm{a}$ & $7.72 \mathrm{a}$ & $3.59 \mathrm{a}$ & $9.12 \mathrm{a}$ & $21.93 \mathrm{a}$ & $56.93 c$ & $11.32 \mathrm{a}$ & $78.87 \mathrm{~b}$ & $0.39 \mathrm{a}$ & $6.97 \mathrm{~b}$ \\
\hline Ecuador & $15.95 b$ & & $31.47 \mathrm{a}$ & $6.39 c$ & $3.74 \mathrm{a}$ & $6.59 b$ & $16.99 b$ & $64.75 \mathrm{a}$ & $10.14 b$ & $81.74 a$ & $0.26 b$ & $8.12 \mathrm{a}$ \\
\hline $\operatorname{LSD}^{\mathrm{e}}$ & 5.673 & & 5.743 & 0.636 & 1.643 & 1.166 & 2.172 & 3.658 & 1.755 & 2.363 & 0.049 & 1.287 \\
\hline
\end{tabular}

${ }^{\mathrm{a}}$ No replication. 


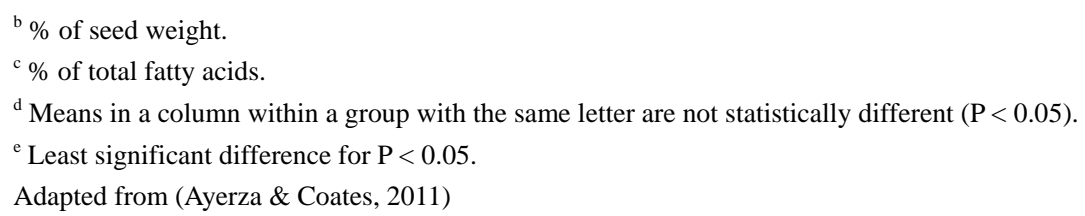

\subsection{Proteins}

When it comes to protein content, chia seeds have dominated the world of oilseeds and most cereal seeds with protein levels ranging from 19-23\%. According to Ayerza \& Coates, (2005) some of the functional characteristics of chia seeds are attributed as a result of the 17-20\% protein content found in the seeds. Protein fraction in a recent characterization review of flour of seed has shown a relatively good equilibrium of essential amino acids especially with regards to cysteine and methionine (Ixtaina, Nolasco \& Tomàs, 2008 ; Sandoval-Oliveros \& Paredes-López, 2013). According to a report by Olivos-Lugo, Valdivia-López \& Tecante, (2010) the chemical store, amino acid profile and the in vitro digestibility tests of chia revealed that high amounts of glutamic acid (123 g/kg of raw protein), arginine (80.6 g/ kg of raw protein), and aspartic acid (61.3 $\mathrm{g} / \mathrm{kg}$ of raw protein) were present in the chia protein. To the contrary, the profiling essential amino acids revealed certain deficiencies as opposed to the World Health Organization standards for young children (FAO/WHO/UNU, 1985). Consequently, chia is not recommended as the only source of proteins thus, supplements which are lysine-rich would be vital since it was the deficient amino acid. On analyzing the protein content of chis seeds, reports according to Ayerza \& Coates, (2011) showed that they varied between regions of growth. The protein content seemed to decrease as the altitude increased and vice versa (Ayerza \& Coates, 2011). Even though chia is found to have limiting amino acid factors when consumed by preschool children and it's not commercially cultivated, Weber points out that its amino acid profile has no effect on adult (Weber et al., 1991). Moreover, when opposed to other traditional cereals such as wheat, rice, oats, barley, and corn its protein content proved superior in both quantity and quality (Ayerza \& Coates, 2005). Further studies and research have also confirmed that chia can be variegated with other cereals and grains to maintain a more balanced and healthy protein source (Fernandez et al., 2005; Pallaro et al., 2004).

\subsection{Dietary Fiber}

Dietary fiber is defined as a mixture of complexes made up of plant carbohydrate polymers, both oligosaccharides and polysaccharides, e.g., cellulose, hemicelluloses, pectic substances, and gums that may be linked with lignin and other non-carbohydrate constituents, e.g., polyphenols, waxes, saponins, cutin, phytates, and resistant protein (Elleuch et al., 2011). Dietary fiber constitutes more than 30\% of the total weight of the seed (Spotorno et al., 2011). Chia seed is a source of dietary fiber at 35\% (Silva et al., 2017), in greater levels as compared to other seeds like amaranth (7.3\%), quinoa (7.0\%), and corn (8.3\%) (Srichuwong et al., 2017).

The concentration of total dietary fiber (TDF) in chia (33.04\%) was found to be higher than in other cereals and oilseeds such as linseed (22.30\%), soy (15.00\%), corn (13.40\%), wheat (12.60\%), and sesame (7.79\%). Out of the total dietary fiber content found in chia, insoluble fiber represented $92 \%(30.37 \pm 1.02 \mathrm{~g} / 100 \mathrm{~g}$ chia) and soluble fiber $8 \%$ (2.67 $\pm 0.26 \mathrm{~g} / 100 \mathrm{~g}$ ) (Dhingra, Michael, Rajput \& Patil, 2012). In a study by Reyes-Caudillo $e t$ al. (2008a), Mexican chia revealed a higher amount of fiber with seeds from the states of Jalisco and Sinaloa being rich in total dietary fiber (TDF) at $39.94 \%$ and $36.97 \%$, respectively. However, a study by Ramzi et al. (2016) reported a lesser value for dietary fiber at $18.15 \%$ as compared to other findings that state dietary fiber ranges between $30-35 \%$. This discrepancy can be explained by the fact that the nutritional composition of chia is influenced by different environmental factors such as; temperature, light and soil composition (Suri, Passi \& Goyat, 2016a). The levels of soluble dietary fiber (SDF) and insoluble dietary fiber (IDF) for Jalisco seeds were 6.84 and $34.9 \mathrm{~g} / 100 \mathrm{~g}$, respectively, while for Sinaloa seeds, the contents were 6.16 and $32.87 \mathrm{~g} / 100 \mathrm{~g}$, respectively. Insoluble fiber is chiefly composed of lignin, cellulose, and hemicellulose, while mucilage is the main type of soluble fiber of the seed (Reyes-Caudillo et al., 2008). This mucilage has high ability for water uptake and can absorb about 27 times its own weight (Mũnoz et al., 2012). The main element of IDF is Klason lignin (KL), which makes up to 39-41\% of TDF; KL allegedly protects unsaturated fats in chia seeds by building a strong and resistant structure and also by the antioxidant compounds present. The amount of neutral sugars in IDF (NSIDF) ranges between $13.79 \%$ to $14.97 \%$, which indicates the presence of cellulose and hemicellulose in disparity with a lower content of uronic acids (UAIDF), 3.05-3.60\%, that represent the amount of glucuronic acid residues associated with insoluble hemicellulose (Valdivia-lópez \& Tecante, 2015). As a result of its capacity to absorb bile acids, lignin is responsible for the hypocholesterolemic effect associated with fiber intake (Valdivia-lópez \& Tecante, 2015). The SDF represents about 6\% of chia seeds (Reyes-Caudillo et al., 2008). 
SDF is predominantly composed of neutral sugars (NSSDF), which shows the presence of various carbohydrates that form the structure of the mucilage. The little quantity of uronic acids (UASDF) suggests that there is no pectin associated with the mucilage, and that the total of UASDF comes from the uronic acid residues found in the polysaccharide chains of the mucilage (Valdivia-lópez \& Tecante, 2015).

\subsection{Antioxidants}

Antioxidants are also an important constituent of chia consisting of majorly phenolic compounds and flavonoids. The phenolic nature of antioxidants present in chia can either be in sugars by glycosidic linkages or in a free form. These glycosidic linkages are responsible for the increased solubility of chia in water (Valdivia-lópez \& Tecante, 2015). According to Ayerza \& Coates, (2011), the most important phenolic compounds are flavanols myricetin, quercetin, kaempferol, and chlorogenic and caffeic acids. Caffeic and rosmarinic acids (Reyes-Caudillo et al., 2008; Capitani et al., 2013; Martinez-Cruz \&Paredes-Lopez, 2014) are some of the identified phenolic compounds in chia products which act majorly in the management and prevention of various neurological conditions such as epilepsy (Coelho et al., 2015). Some of the advantages of caffeic acid found in chia are memory protective effect and hypoglemic activity. In salvia species, rosmarinic acid is reported to be predominant and widely known for its immunorugulatory activities including but not limited to; anti-inflammatory and antioxidant activities, anti-diabetic effect and antimicrobial effect (Jayanthy \& Subramanian, 2014). Moreover, it is associated with the ability to inhibit inflammatory process that is related to ischemia reperfusion (Rocha et al., 2015). In chia seed antioxidant composition, rosmarinic acid possesses the greatest percentage amounting to $(0.927 \mathrm{mg} / \mathrm{g})$, seconded by protocatechuic acid $(0.747 \mathrm{mg} / \mathrm{g})$, caffeic acid $(0.027 \mathrm{mg} / \mathrm{g})$, and gallic acid $(0.012 \mathrm{mg} / \mathrm{g})$. In addition, ferulic acid, glycitin, genistin, glycitein, and genistein were also detected in chia. (Mart'inez-Cruz \& Paredes-L'opez, 2014). In a study carried out by, Marineli et al., (2014), chia seed extract revealed the existence of chlorogenic acid $(353.09 \mathrm{mg} / \mathrm{g})$, quercetin $(301.04 \mathrm{mg} / \mathrm{g})$, myricetin $(317.04 \mathrm{mg} / \mathrm{g})$ and decarboxymethyl elenolic acid linked to hydroxytyrosol (3,4-DHPEA-EDA) ( $377.13 \mathrm{mg} / \mathrm{g}$ ) but caffeic acid and kaempferol were absent in the tested samples. The differences identified may be attributed to a set of variable such as extraction techniques, identification methods, and losses during analysis, region of cultivation of seeds and equipment used. All these factors have a significant contribution to the diverse content of bioactive compounds (Ayerza \& Coates, 2011). Flavonoids have also been found to be in high quantities as flavones and flavanones. Phytates and tannins traces can be found in relatively smaller quantities but antioxidant compounds such as vitamin $\mathrm{E}$ and carotenoids are found in greater quantities (Silva et al., 2017; Oliveira-Alves et al., 2017).

\subsection{Minerals and Vitamins}

Chia is an outstanding source of minerals such as potassium, zinc, calcium, phosphorus and copper (Ayerza, 2001). The most significant minerals in chia include; calcium (631 mg.100 g 1), potassium (407 mg.100 g 1 ), magnesium (335 mg.100 g-1), iron (7.72 mg.100 g-1) and zinc (4.58 mg.100 g-1) (USDA. 2015). Studies by Ullah et al. (2016), reported that macronutrients in chia seeds are composed of; phosphorus 860, calcium 631, potassium 407, and magnesium $335 \mathrm{mg} / 100 \mathrm{gm}$, and microelements; selenium $55.2 \mu \mathrm{g} / 100 \mathrm{~g}$, sodium $16 \mu \mathrm{g} / 100$ $\mathrm{g}$, iron $7.72 \mu \mathrm{g} / 100 \mathrm{~g}$, manganese $2.72 \mu \mathrm{g} / 100 \mathrm{~g}$, zinc $4.58 \mu \mathrm{g} / 100 \mathrm{~g}$, copper $0.924 \mu \mathrm{g} / 100 \mathrm{~g}$ and molybdenum $0.2 \mu \mathrm{g} / 100 \mathrm{~g}$. The phosphorous, calcium and potassium content of chia seed is greater than that of other crops such as wheat, rice, oats and corn (Beltran-Orozco \& Romero, 2003). Furthermore, chia also contains vitamins such as niacin $(8.83 \mathrm{mg} / 100 \mathrm{~g})$, thiamine $(0.62 \mathrm{mg} / 100 \mathrm{~g})$ and riboflavin $(0.17 \mathrm{mg} / 100 \mathrm{~g})$, with higher levels as compared to different seeds (Mũnoz et al., 2012).

\section{Physical Properties of Chia}

The physical properties of chia seeds dictate the importance of establishing and developing necessary machines for transportation, handling, storage, drying and additional industrial activities such as extraction of oil. To understand the complexity of chia seed cultivation, distribution, adequate design for cleaning equipment, grading and separation technology, moisture content analysis to effect the drying process, understanding on the morphology and size distribution is essential (Kachru, Gupta \& Alam, 1994). In a study conducted by Ixtaina et al., (2008), the moisture content was observed to be 7.2 and $6.6 \%$ for dark and white chia seeds, correspondingly. In addition, Longitudinal measurement $(L)$ ranged from 1.73 to $2.63 \mathrm{~mm}$. The bulk of chia seeds $(59 \%$ of dark seed and $62 \%$ of white seed by number) were medium-sized $(2.00 \leq L \leq 2.25 \mathrm{~mm})$. The average seed width and thickness were $1.32-0.81 \mathrm{~mm}$ and $1.40-0.83 \mathrm{~mm}$ for dark and white seeds, in that order. These findings were in the same range as those reported by Rulfo, (1937) for chia seeds. These dimensions of chia seeds were found to lie within the same range to quinoa and rapeseed seeds but were found to be higher than amaranth seeds. Also, these dimensions were found to be lower than cumin, pearl millet, sesame, safflower, flaxseed and coriander 
(Vilche, Gely \& Santalla, 2003; Cahsir, Glu, "Og־u", \& O. ztu, 2005; Abalone , Cassinera \& Lara, 2004; Coskuner \& Karababa, 2007).

The bulk density ranged from 0.667 to $0.722 \mathrm{~g} \mathrm{~cm}^{-3}$ for white and dark seeds respectively, with the bulk density of white chia seed $\left(0.667 \mathrm{~g} \mathrm{~cm}^{-3}\right)$ being ascribed to its bigger size. The true density and porosity was observed to be between 0.931 and $1.075 \mathrm{~g} \mathrm{~cm}-3$, and 22.9 and $35.9 \%$ for white and dark chia seeds respectively (Ixtaina et al., 2008). As compared to sunflower, safflower and coriander the true density was found to be higher (Gupta \& Das, 1997; Baümler, Cuniberti, Nolasco, \& Riccobene, 2006 ; Coskuner \& Karababa, 2007). However, it was lesser than amaranth, sesame, soybeans and millet (Abalone et al., 2004; Tunde-Akintunde \& Akintunde, 2004). Further, Ixtaina et al., (2008) recounted that the equivalent diameter and sphericity of dark and white chia seeds were in the range of 1.32 to $1.39 \mathrm{~mm}$, and 62.2 to $66.0 \%$, geometric mean diameter ranged from 1.10 to $1.54 \mathrm{~mm}$ and surface area of each seed was $5.42 \pm 0.15 \mathrm{~mm}^{2}$ and $5.79 \pm 0.12 \mathrm{~mm}^{2}$ for the dark and white seeds. Guiotto et al., (2011), also reported that the average of the specific surface area $(S)$ for both white and black chia seeds was $5.20 \mathrm{~mm}^{2}$.

The mean values of volume were 1.21 and $1.12 \mathrm{~mm}^{3}$ for dark and white seeds as reported by (Guiotto et al., 2011), while according to (Ixtaina et al., 2008) the volume of single chia grain (V)

was in the range of 1.19 to $1.42 \mathrm{~mm}^{3}$. The aspect ratio of chia seed was $62.7 \pm 1.5 \%$ and $65.3 \pm 1.3 \%$ for dark and white seeds. In view of the low aspect ratio (seeds width to length) and sphericity, it may be presumed that chia seeds would slide on their flat surfaces other than roll. This propensity to either roll or slide is very important in the design of hoppers, since most flat seeds slide more easily than spherical seeds, which tend to roll on structural surfaces (Ixtaina et al., 2008).

\section{Functional Properties of Chia Seeds}

Products that are rich in protein often show different functional characteristics that are often predominant as compared to characteristics of the source flour (Rodri'guez, Rez \& Dufour, 2011) The preference of the products is established when simplifying the extraction process or in case of existence of other components, which as a result pose the threat of complicating the separation process or lead to the loss of essential components. This can be evident in cases of wet extraction (Bergthaller, Dijkink, Langelaan \& Vereijken, 2001). Food proteins get their function characteristics from their charge distribution, three dimensional structures and their molecular sizes. The behavior of proteins when they interact with themselves and other components in a complex food system is determined by their structure-function relationship (Joshi, Adhikari, Aldred, Panozzo \& Kasapis, 2011). The most essential functional properties of protein in food include water- and fat-binding, hydration, rheological behaviors, foaming and emulsifying. Environmental factors such as climate and other processing conditions greatly affect these properties (Shevkani, Singh, Kaur \& Rana, 2015).

The water and oil holding capacity of foods rich in protein is influenced by inherent factors like protein conformation, amino acid structure and surface polarity or hydrophobicity of the food (Haripriya \& Aparna, 2018). For example, the water holding capacity WHC (the ability of a moist material to keep water when imperiled to an external centrifugal gravity force or compression (Alfredo, Gabriel, Luis \& David, 2009), of flour is carefully linked to both amount of amino acids in various flours and accessibility of proteins functional groups within the flour (Kouakou et al., 2013). In a study by (Taylor, Vázquez-ovando, Betancur-ancona \& Chel-guerrero. (2012), chia fibrous rich fraction displayed a water holding capacity of 15.4 times of its weight. This value is greater than that reported for fibrous fractions obtained from soy, wheat and maize hulls (Cruz-Salazar, 2002). The mucilaginous fraction obtained from chia may contribute to WHC because mucilages are known to have exceptional water-holding features. Fiber arrangement may also enhance WHC (Pez et al., 1997) and the high quantities of hemicellulose and lignin (both have a certain amount of WHC) in the chia FRF may have improved this property. Haripriya and Aparna, (2018), observed that water absorption levels of untreated and roasted chia seeds were $5.2 \pm 0.25 \mathrm{ml} / \mathrm{g}$, and $2.7 \pm 0.30 \mathrm{ml} / \mathrm{g}$ respectively while chia defatted meals demonstrated a WHC of 9.2 to $10.13 \mathrm{~g} / \mathrm{g}$. Alfredo et al. (2009), described that the fiber structure and high amounts of hemicellulose and lignin may contribute to the high WHC values acquired for chia seeds and their derivatives.

Oil holding capacity (OHC) on the other hand is an essential property to develop novel food products and store them for a long period (Haripriya \& Aparna, 2018). Chia mucilage showed higher OHC (5.85 g oil/ g sample) than both whole seeds and powder (3.5, $2.5 \mathrm{~g}$ oil/ g sample) respectively (Darwish, Khalifa \& Sohaimy, 2018). These results could suggest that chia mucilage can be used as a stabilizer and emulsifier which previously mentioned by (Salgado-Cruz et al., 2013; Suri et al., 2016). The oil absorption capacity of untreated and roasted chia seeds as reported by Haripriya \& Aparna, (2018) were $0.9 \pm 0.26 \mathrm{ml} / \mathrm{g}, \& 0.8 \pm 0.32 \mathrm{ml} / \mathrm{g}$ respectively. Alfredo 
et al. (2009) also informed that the fiber-rich chia fraction revealed a low oil-holding capacity $(2.2 \mathrm{~g} / \mathrm{g})$. Furthermore, Vázquez-ovando et al. (2013) described that the chia fibrous rich fraction (FRF) had a low oil-holding capacity $(\mathrm{OHC})$ of $2.02 \mathrm{~g}$ oil/g sample. The particle size may affect the $\mathrm{OHC}$ in that smaller particles have comparatively more contact surface and therefore would theoretically hold more oil (Lo' pez et al., 1997). As a result of its low OHC, Vázquez-ovando et al. (2013) reported that chia fibrous rich fraction can be utilized as a possible ingredient in fried products since it would offer a non-greasy perception.

The capability of chia flour to form gels is reliant on the swelling capacity and solubility of chia seeds. These two factors are linked to the interaction of the chia flour components with the water molecules (Munoz et al., 2012). The swelling capacity is the volume of expansion of molecule due to the consumption of water up to a level where the colloidal suspension is complete (Ayernor \& Ocloo, 2002). The swelling capacity of untreated and roasted chia seed powder were recorded as, $8.5 \pm 1.74 \%$ and $6.3 \pm 0.53 \%$ respectively (Haripriya and Aparna, 2018). Chia mucilage is highly soluble in water at $50 \mathrm{~g} / \mathrm{ml}$ hence it has a potential industrial use, as it is reflected that gums and/or mucilages with higher solubility possess better quality (Mhinzi \& Mrosso, 1995). According to Capitani et al. (2013), the water adsorption capacity (WAbC) of chia meals with and without mucilage was higher $5.25 \pm 0.39 \mathrm{~g} / \mathrm{g}$ and $10.64 \pm 0.60 \mathrm{~g} / \mathrm{g}$ than that witnessed for canola and soybean meals $(3.90 \mathrm{~g} / \mathrm{g}$ and 3.28 $\mathrm{g} / \mathrm{g}$, correspondingly) and alike to that of linseed meal $(6.03 \mathrm{~g} / \mathrm{g})$ (Khattab \& Arntfield, 2009). Capitani et al. (2013), also observed that chia seeds meals with and without mucilage did not reveal any differences in the emulsifying activity although the stability of the emulsion prepared with chia seed meal with mucilage was statistically higher than the chia meal without mucilage. This effect can be linked with the ability of mucilage to act as a thickening agent owing to its ability to raise the viscosity of the aqueous phase in an O/W emulsion, hence preventing the movement of the oil droplets of the distributed phase (McClements, 1999). This feature is similar in the linseed mucilage, which has a robust thickening capacity, favorably influencing the water-holding capacity and the emulsifying features of defatted linseed flour (Dev \& Quensel, 1986).

\section{Health Benefits of Chia}

There is current evidence presenting the health benefits linked with the consumption of foods predominant in omega-3 (Vannice \& Rasmussen, 2014). Chia seeds constitute a vital plant source of n-3 PUFA to be exploited in diverse research models for human health and the prevention of diseases. This is owing to its rich nutritional profile consisting of proteins, minerals, fiber, polyphenols, and polyunsaturated fatty acids (PUFAs) and is presently recognized as one of the best plant sources of the omega- $3(n-3)$ fatty acid, $\alpha$ - linolenic acid (ALA) (Mohd et al., 2012). Certain rodent experiments have demonstrated that chia may reduce serum cholesterol, LDL (low density lipoproteins), and triglycerides while raising HDL (high density lipoproteins) ( Ayerza \& Coates, 2007). Alpha linolenic acid (ALA) from chia may also increase adiposity, blood lipid parameters, and insulin resistance in dyslipidemic rats (Chicco, D'Alessandro, Hein, Oliva, \& Lombardo, 2009) Moreover, chia has been established to display anti-tumor activity in murine mammary gland adenocarcinoma (Espada, Berra, Martinez, Eynard, A \& Pasqualini, 2007). A study by Vuksan et al. (2016), recommended that chia was more effective than flax in affecting postprandial outcomes such as postprandial glycemia and satiety. Three previous studies have assessed the effects of chia in respect to blood pressure (BP). Vuksan et al. (2007) established a reduction in systolic BP $(-6.3 \pm 4 \mathrm{mmHg})$ in diabetic patients who consumed $37 \mathrm{~g} /$ day of chia seeds for 12 weeks. Nevertheless, Nieman et al. (2009) observed that there were no changes in BP in overweight or obese adults who ingested $50 \mathrm{~g} /$ day of chia seeds for 12 weeks. A comparable result was stated by Nieman et al. (2012) who also established no changes in BP in overweight women who consumed $25 \mathrm{~g} /$ day of chia seeds for 10 weeks. Toscano and Surama, (2014), determined the effect of 12 week duration of chia flour supplementation using clinical and 24-h ambulatory measurements. They also identified whether oxidative stress, inflammation and endothelial functions are linked with the potential lowering of BP in pharmacologically untreated hypertensive persons and in those formerly treated with drug therapy. They concluded that the intake of chia flour is steadily able to decrease the BP in hypertensive individuals and in patients previously treated with medicine in a manner comparable to the patients not under any medication. Moreover, substitute antihypertensive drugs are being researched on due to the high cost, side effects, and safety issues of current drugs. Indications suggests that palatable foods such as milk, egg, plants, and grains have peptides involved in the prevention and lowering of high blood pressure (Hernández-Ledesma, Contreras, del \& Recio, 2011 ; Montoya-Rodri'guez, Go'mez-Favela, Reyes-Moreno, Milán-Carrillo \& Mejı́a, 2015; Rosales-Mendoza, Paz-Maldonado, Govea-Alonso \& Korban, 2013). A study by Orona-Tamayo, Valverde \& Pez. (2016), accounted that the ACE-inhibitory peptides resultant from explicit protein fractions of chia seeds can be a natural remedy for hypertensive persons when they ingest chia as a supplement. In a study to define whether 6-month dietary inclusion of chia would prompt a substantial weight reduction likened to an oat bran-based control; when consumed in combination with a calorie-restricted 
diet, and added on top of conventional treatment in overweight and obese individuals with type 2 diabetes (T2DM), Vuksan et al., (2017) reported that there is an advantageous role of Salba-chia seeds in promoting weight loss and improvements of obesity related risk factors, while preserving good glycemic control. Supplementation of Salba-chia may be a valuable dietary addition to conventional therapy in the management of obesity in diabetes. While examining the effects of dietary chia seed and oil on plasma and liver oxidative status in diet-induced obese rats, no differences in plasma and liver superoxide dismutase activity between chia diets and high-fat and high-fructose diet (HFF) group. Chia (seed and oil) consumption did not change liver lipid peroxidation, but was able to decrease plasma thiobarbituric acid reactive substances (TBARS) and 8-isoprostane amount increased by HFF group. Plasma and hepatic antioxidant capacity values were raised in chia seed and oil groups at $35 \%$ and $47 \%$, correspondingly, compared to HFF group. Dietary chia seed and oil lowered oxidative stress in vivo, as it enhanced antioxidant status and lowered lipid peroxidation in diet-induced obese rats ( Marineli et al., 2015). However, they added that consideration is necessary before inferring these findings to humans and proposed that the quantity of chia tested in the current study should be further tested in clinical studies for chia oil diet replacement or introduction of chia seed in normal human nutrition. The amino acids present in chia seeds are vital for numerous human metabolic activities. Precisely, glutamic acid has the capability to stimulate the central nervous system, is involved in its immunologic performance and increases athletic stamina (Brosnan \& Brosnan, 2013 and Paredes Lo'pez, 1991). Aspartic acid on the other hand stimulates hormonal regulation for the appropriate functionality of the nervous system (Brosnan \& Brosnan, 2013). Other amino acids like arginine apparently guard against cardiovascular diseases (Bo"ger, 2007) and sulfur amino acids may be involved in the functionality of the tertiary and also quaternary structures of the proteins (Sandoval-Oliveros \& Paredes-Lo'pez, 2013). The above annotations propose that the quality of chia proteins and their amino acids is similar or higher than other vital cereals and oilseeds. The occurrence of these biomolecules in chia seeds epitomizes an essential nutraceutical impact to the daily diet (Sandoval-Oliveros \& Paredes-Ló́pez, 2013).

\section{Utilization of Chia in the Food Industry}

The superior nutritional quality of chia seeds potentiates the use of chia in application in various foods as a functional food (Munoz et al., 2012). Chia is used as whole seeds, chia flour or ground chia, soaked in water or in dry form. Based on the use, only mucilage or oil undergoes farther processing (Zettel \& Hitzmann, 2018).

Chia seed gel possesses abilities that allow its use in numerous products in the food industry (Ali et al., 2012) such as thickener, gel former and chelator (Capitani et al., 2012). Moreover, it can act as a fat replacer since it has the ability to hydrate, improve viscosity and conserve freshness, principally in baked products (Vázquez-ovando, Betancur-ancona, Chel-guerrero, Betancur-ancona \& Chel-guerrero, 2013). This potential property is used in developing products with reduced fat and that can be used as functional foods due to the fiber content. According to Fernandes \& Salas-mellado, (2017), breads and chocolate cakes prepared with chia mucilage can substitute up to $50 \%$ of fat without influencing the technological and physical features. Consequently, chia mucilage is a new alternative for substituting fat in food products, conserving the quality characteristics and ensuring healthier foods. Also, chia mucilage could be used in the food industry as a foam stabilizer, a suspending agent, emulsifier, adhesive or binder, due to its water holding capacity, and viscosity (Salgado-Cruz et al., 2013). The mucilage acquired from chia seeds is a novel source of polysaccharides and could potentially generate remarkable polymer blends for edible films and coatings (Mũnoz et al., 2012).

Dick et al. (2015), produced novel, biodegradable edible films using only chia mucilage as the principal raw material and reported that edible films plasticized with glycerol can be prepared successfully. Additionally, it was observed that chia mucilage films exhibited high solubility in water, good thermal resistance, transparency, and UV light barrier properties, which could provide increased protection to packaged food. This study revealed that chia mucilage films have potential as edible film or coating, with the health benefits of chia mucilage soluble dietary fiber.

Studies have also revealed that chia protein hydroslates when used in white bread and carrot cream increased product biological potential without remarkably changing product quality (Segura-campos et al., 2013). Additional studies have also exposed that chia gel can substitute as much as $25 \%$ of oil or eggs in cakes while giving a more nutritious product with acceptable sensory parameters (Borneo, Aguirre \& León, 2010). These authors indicated that replacing eggs or oil in the cake formulation with chia gel up to a level of $25 \%$ retained the functional and sensory properties of the product. However, they recommended that more research is needed to optimize functional and sensory characteristics of cakes with chia gel. The assimilation of chia oil into functional oil in water $(\mathrm{O} / \mathrm{W})$ emulsions was also studied by Magdalena et al. (2015), who reported that $\mathrm{O} / \mathrm{W}$ emulsions are a possible alternative system to enhance chia oil stability against lipid oxidation thus chia oil can be integrated 
into oil-in-water $(\mathrm{O} / \mathrm{W})$ emulsions as $\omega-3$ fatty acid delivery systems in food matrices. Chia flour has also been used to develop bread with improved nutritional value and healthy features that can be used not only by persons with celiac disease but also sustain health status of people with various diseases. It was observed that chia flour contains no gluten and can be used by patients with celiac disease (Costantini et al., 2014). The incorporation of chia into dairy products such as yoghurt and ice-cream has also increased (Chavan, Gadhe, Dipak \& Hingade, 2017; (Chavan et al., 2017; Campos, Ruivo, Scapim, Madrona \& Bergamasco, 2016) tested the use of chia as a thickener in the manufacture of ice-cream while Ayaz et al. (2017) also included chia seeds in yoghurt which gave the feeling of short-term satiety.

In other studies, an assessment of the possibility to increase B. infantis ATCC 15679 and L. plantarum ATCC 8014 survival after spray drying using mucilage and soluble protein fractions from chia seeds or flaxseed as encapsulating materials was carried out. Findings exhibited that the mucilage and soluble protein fractions obtained from chia seed and flaxseed enhanced probiotic (B. infantis and L. plantarum) survival during spray drying and viability during storage at $4{ }^{\circ} \mathrm{C}$ when used as constituents of the encapsulation solution with maltodextrin. Furthermore, cells encapsulated with the seed fractions improved resistance against simulated gastric conditions. These results revealed that chia seed and flaxseed are exceptional sources of probiotic encapsulating agents (Bustamante, Oomah, Rubilarb\& Shene, 2016).

\section{Environmental Impact}

The chia plant can be utilized as a whole in the following ways: chia seeds to obtain oil for food applications and cosmetology, cake meals for animal feeds and the leaves and whole plants for ensiling. Consequently, the promotion of chia as a potential crop for food and nutrition security in Africa does not pose any adverse effects to the environment.

\section{Conclusion}

In the recent years there has been an increased demand for functional food products that possess numerous health benefits as well as provide basic nutrients due to the emerging trend towards a healthy lifestyle. This review shows that chia seeds contain superior nutritional components as compared to other seeds and also confers many health benefits such as antioxidative, anti-hypertensive and hypoglycemic properties among others. Furthermore, its physical and functional properties make it an excellent crop to be used in food applications in the development of functional foods and its application is not only limited to food but can also be used in feed. However, most of the chia based research has been conducted in America and hence new investigations that focus on chia cultivated in Africa are necessary so as to demonstrate its potential as a crop for food and nutrition security.

\section{References}

Abalone, R., Cassinera, A., On, A. G., \& Lara, M. (2004). Some physical properties of Amaranth seeds. Biosyst. Eng, 89, 109-117. https://doi.org/10.1016/j.biosystemseng.2004.06.012Homa Mahmoodzadeh

Ahmed, M., Ting, I., \& Scora, R. (1994). Leaf oil composition of Salvia hispanica L. from three geographical areas. J Essent Oil Res, 6, 223-228. https://doi.org/10.1080/10412905.1994.9698368

Alfredo, V., Gabriel, R., Luis, C., \& David, B. (2009). Physico chemical properties of fibrous fraction from chia (Salvia hispanica L.). LWT-Food Science and Technology, 42, 168-173. https://doi.org/10.1016/j.lwt.2008.05.012

Ali, N. M., Yeap, S. K., Ho, W. Y., Beh, B. K., Tan, S. W., \& Tan, S. G. (2012). The Promising Future of Chia, Salvia hispanica L. Journal of Biomedical Biotechnology, 2012, 1-9. https://doi.org/10.1155/2012/828139

Amato, M., Caruso, M. C., Guzzo, F., Galgano, F., Commisso, M., Bochicchio, R., ... Favati, F. (2015). Nutritional quality of seeds and leaf metabolites of Chia ( Salvia hispanica L.) from Southern Italy. European Food Research and Technology. https://doi.org/10.1007/s00217-015-2488-9

Anacleto, S., Guadalupe, R., Jat, R., Gerardo, G., Heather, W., Maneesh, S., ... Torre, R. de la. (2016). Chia Crop (Salvia hispanica L.): its History and Importance as a Source of Polyunsaturated Fatty Acids Omega-3 Around the World: a Review. Journal of Crop Research and Fertilizers, 1, 1-9. https://doi.org/10.17303/jcrf.2016.104

Artcos, S. D. (2018). Collaborative collection management solution. Arctos Plants. Retrieved from http://arctos.database.museum/name/Salvia hispanica\#

Ayaz, A., Akyol, A., Inan-Eroglu, E., Cetin, A. K., Samur, G., \& Akbiyik, F. (2017). Chia seed (salvia hispanica 
1.) added yogurt reduces short term food intake and increases satiety: randomised controlled trial. Nutrition Research and Practice, 11(5), 412-418. https://doi.org/10.4162/nrp.2017.11.5.412

Ayernor, G., \& Ocloo, F. C. (2002). Physiochemical changes and diastatic activity associated with germinating paddy rice (PSB.RC 34). African Journal of Food Science, 1, 37-42.

Ayerza, R. (1995). Oil content and fatty acid composition of chia (Salvia hispanica L.) from five northwestern locations in Argentina. Journal of the American Oil Chemists'Society, 72(9), 1079-1081. https://doi.org/10.1007/BF02660727

Ayerza, R. (2001). Wax-ester composition of ten jojoba clones growing in two arid ecosystems of South America. Journal of Tropical Science, 41, 168-171.

Ayerza, R. (2010). Effects of seed color and growing locations on fatty acid content and composition of two chia (Salvia hispanica L.) genotypes. Journal of the American Oil Chemists Society, 87(10), 1161-1165. https://doi.org/10.1007/s11746-010-1597-7

Ayerza, R., \& Coates, W. (2007). Effect of dietary alpha-linolenic fatty acid derived from chia when fed as ground seed, whole seed and oil on lipid content and fatty acid composition of rat plasma. Ann Nutr Metab, 5l(1), 27-34. https://doi.org/10.1159/000100818

Ayerza, R., \& Coates, W. (2005). Chia Rediscovering a Forgotten Crop of the Aztecs. Tucson, AZ, USA.

Ayerza, R, \& Coates, W. (2004). Composition of chia ( Salvia hispanica) grown in six tropical and subtropical ecosystems of South America. (October 2003), 131-135. https://doi.org/10.1002/ts.154

Ayerza, R., \& Coates, W. (2011). Protein content, oil content and fatty acid profiles as potential criteria to determine the origin of commercially grown chia ( Salvia hispanica L .). Journal of Industrial Crops and Products, 34, 1366-1371. https://doi.org/10.1016/j.indcrop.2010.12.007

Bau"mler, E., Cuniberti, A., Nolasco, S., \& Riccobene, I. (2006). Moisture dependent physical and compression properties of safflower seed. Journal of Agricultural Engineering, 72, 134-140. https://doi.org/10.1016/j.jfoodeng.2004.11.029

Beltran-Orozco, M., \& Romero, M. (2003). La chia, alimento milenario. Mexico.

Bergthaller, W., Dijkink, B., Langelaan, H., \& Vereijken, J. (2001). Protein from pea mutants as a co-product in starch separation. Isolates from wet and dry separation: Yield, composition and solubility. Nahrung-Food, 45, 390-392. https://doi.org/10.1002/1521-3803(20011001)45:6<390::AID-FOOD390>3.0.CO;2-\#

Bo"ger, R. (2007). The pharmacodynamics of L-arginine. Journal of Nutrition, 137, 1650S_1655S. https://doi.org/10.1093/jn/137.6.1650S

Bochicchio, R., Rossi, R., Labella, R., Bitella, G., \& Perniola, M. (2015). Effect of sowing density and nitrogen top-dress fertilization on growthand yield of chia (Salvia hispanica L.) in a Mediterranean environment: first results. Italian Journal of Agronomy, 10, 163-166. https://doi.org/10.4081/ija.2015.640

Borneo, R., Aguirre, A., \& León, A. E. (2010). Chia (Salvia hispanica L) Gel Can Be Used as Egg or Oil Replacer in Cake Formulations. YJADA, 110(6), 946-949. https://doi.org/10.1016/j.jada.2010.03.011

Bustamante, M., Oomah, B. D., Rubilar, M., \& Shene, C. (2016). Effective Lactobacillus plantarum and Bifidobacterium infantis encapsulation with chia seed (Salvia hispanica L.) and flaxseed (Linum usitatissimum L.) mucilage and soluble protein by spray drying. Food Chemistry. https://doi.org/10.1016/j.foodchem.2016.08.019

Cahill, J. (2003). No Title. Economic Botany, 57, 604-618. https://doi.org/10.1663/0013-0001(2003)057[0604:EOCSHL]2.0.CO;2

Cahill, J. P., \& Provance, M. C. (2002). Genetics of qualitative traits in domesticated chia (Salvia hispanica L.). Journal of Heredity, 93(1), 52-55. https://doi.org/10.1093/jhered/93.1.52

Cahsir, S., Glu, T. M.,"Ogü", T. H., \& Rk, O. O. Z. (2005). Physical properties of rapeseed (Brassica napus oleifera L.). Journal of Food Enngineering, 69, 61-66. https://doi.org/10.1016/j.jfoodeng.2004.07.010

Campos, B., Ruivo, T. D., Scapim, M. da S., Madrona, G., \& Bergamasco, R. de C. (2016). Optimization of the mucilage extraction process from chia seeds and application in ice cream as a stabilizer and emulsifier. $L W T$ - Food Science and Technology, 65, 874-883. https://doi.org/10.1016/j.lwt.2015.09.021

Capitani, M. I., Nolasco, S. M., \& Tomás, M. C. (2013). Effect of Mucilage Extraction on the Functional Properties of Chia Meals. Food Industry, 422-437. 
Castro, G. M. (2002). Ácidos grasos Omega 3: beneficios y Fuentes. Interciencía, 27, 128-136.

Chavan, V., Gadhe, K., Dipak, S., \& Hingade, S. (2017). Studies on extraction and utilization of chia seed gel in ice cream as a stabilizer. Journal of Pharmacognosy and Phytochemistry, 6(5), 1367-1370.

Chicco, A., D’Alessandro, M., Hein, G., Oliva, M., \& Lombardo, Y. (2009). Dietary chia seed (Salvia hispanica L.) rich in alpha-linolenic acid improves adiposity and normalizes hypertriacylglycerolaemia and insulin resistance in dyslipaemic rats. Br J Nutr, 101(1), 41-50. https://doi.org/10.1017/S000711450899053X

Chilliard, Y., Ferlay, A., \& Doreau, M. (2001). Effect of different types of forages, animal fat or marine oils in cow's diet on milk fat secretion and composition, especially conjugated linoleic acid (CLA) and polyunsaturated fatty acids. Journal of Livestock Production Science, 70, 31-48. https://doi.org/10.1016/S0301-6226(01)00196-8

Coates, W., \& Ayerza, R. (1996). Production potential of chia northwestern Argentina. Journal of Industrial Crop and Products, 5, 229-233. https://doi.org/10.1016/0926-6690(96)89454-4

Coelho, V., Vieira, C. G., Souza, L., Moyses, F., Basso, C., Papke, D. K., ... Pereira, P. (2015). Antiepileptogenic, antioxidant and genotoxic evaluation of rosmarinic acid and its metabolite caffeic acid in mice. Journal of Life Sciences, 121, 65-71. https://doi.org/10.1016/j.lfs.2014.11.009

Commission, E. (2009). Commission decision authorizing the placing on the market of Chia seed (Salvia hispanica) as novel food ingredient under Regulation (EC) No 258/97 of the European Parliament and of the Council.

Commission, E. (2013). Commission implementing decision authorizing an extension of use of Chia (Salvia hispanica) seed as a novel food ingredient under Regulation (EC) No 258/97 of the European Parliament and of the Council. Off J Eur Union L21/34.

Coorey, R., Tjoe, A., \& Jayasena, V. (2014). Gelling Properties of Chia Seed and Flour. Journal of Food Science, 79(5), 859-866. https://doi.org/10.1111/1750-3841.12444

Coskuner, Y., \& Karababa, E. (2007). Physical properties of coriander seeds (Coriandrum sativum L.). Journal of Food Enngineering, 80, 408-416. https://doi.org/10.1016/j.jfoodeng.2006.02.042

Costantini, L., Lukšič, L., Molinari, R., Kreft, I., Bonafaccia, G., Manzi, L., \& Merendino, N. (2014). Development of gluten-free bread using tartary buckwheat and chia flour rich in omega-3 fatty acids and flavonoids as ingredients. Food Chemistry. https://doi.org/10.1016/j.foodchem.2014.05.095

Craig, R. (2004). Application for approval of whole chia (Salvia hispanica L.) seed and ground whole seed as novel food ingredient (Company Re; N. I. (2004). Mr D Amstrong, Ed.). Northern Ireland.

Cruz-Salazar, M. (2002). Caracterización del residuo fibroso obtenido de la ca'scara de maracuya' Passiflora edulis Flavicarpa Dagener. de Maestrı'a. Universidad Auto'noma de Yucata' n, Me' xico.

Darwish, A. M. G., Khalifa, R. E., \& Sohaimy, S. A. El. (2018). Functional Properties of Chia Seed Mucilage Supplemented In Low Fat Yoghurt. https://doi.org/10.21608/asejaiqjsae.2018.13882

Dev, D., \& Quensel, E. (1986). Functional and microestructural characteristics of linseed (Linum usitatissimum L.) flour and a protein isolate. Lebensmittel Wissenschaft and Technology - Food Science Technology, 19, 331-337.

Dewhurst, R. J., Fisher, W. J., Tweed, J. K. S., \& Wilkins, R. J. (2003). Comparison of grass and legume silages for milk production. 1. Production responses with different levels of concentrate. Journal of Dairy Science, 86, 2598-2611. https://doi.org/10.3168/jds.S0022-0302(03)73855-7

Dewhurst, R., Shingfield, K., Lee, M., \& Scollan, N. (2006). Increasing the concentrations of beneficial polyunsaturated fatty acids in milk produced by dairy cows in high-forage systems. Journal of Animal Feed Science, 131, 168-206. https://doi.org/10.1016/j.anifeedsci.2006.04.016

Dhingra, D., Michael, M., Rajput, H., \& Patil, R. (2012). Dietary fibre in foods: a review. Journal of Food Science and Technology, 49, 255-266. https://doi.org/10.1007/s13197-011-0365-5

Dick, M., Maria, T., Costa, H., Gomaa, A., Subirade, M., Oliveira, A. De, \& Hickmann, S. (2015). Edible film production from chia seed mucilage: Effect of glycerol concentration on its physicochemical and mechanical properties. Carbohydrate Polymers, 130, 198-205.

https://doi.org/10.1016/j.carbpol.2015.05.040

Dubernard, C. (1991). Códices de Cuernavaca y unos títuᄀlos de sus pueblos. Porrúa., 396. 
Elleuch, M., Bedigian, D., Roiseux, O., Besbes, S., Blecker, C., \& Attia, H. (2011). Dietary fibre and fibre-rich by-products of food processing: Characterisation, technological functionality and commercial applications: A review. Journal of Food Chemistry, 124, 411-421. https://doi.org/10.1016/j.foodchem.2010.06.077

Espada, C., Berra, M., Martinez, M., Eynard, A., \& Pasqualini, M. (2007). Effect of Chia oil (Salvia hispanica) rich in omega-3 fatty acids on the eicosanoid release, apoptosis and T-lymphocyte tumor infiltration in a murine mammary gland adenocarcinoma. Prostaglandins Leukot. Journal of Essentual Fatty Acids, 77(1), 1-8. https://doi.org/10.1016/j.plefa.2007.05.005

FAO/WHO/UNU. (1985). Energy and protein requirements- Report of a joint FAO/ WHO/UNU expert consultation: Technical report series. Geneva: WHO.

Fernandes, S. S., \& Salas-mellado, M. D. M. (2017). Addition of chia seed mucilage for reduction of fat content in bread and cakes. Food Chemistry, 227, 237-244. https://doi.org/10.1016/j.foodchem.2017.01.075

Fernandez, I., Vidueiros, S., Feliu, M., Angellini, E., Ayerza, R., Coates, W., ... Pallaro, A. (2005). Calidad proteica de nuevos viejos cultivos característicos de Mesoamérica y Sudamérica: quinoa y chia. VIII. Congreso Nacional Bioquímico de La República Argentina, 76. San Juan, Argentina,: Libro de Resúmenes.

Guiotto, E. N., Ixtaina, V. Y., C.Tomás, M., \& Nolasco, S. M. (2011). Moisture dependent physical propertie of Chia. American Society of Agricultural and Biological Engineers, 54(2), 527-533. https://doi.org/10.13031/2013.36455

Guiotto, E. N., Ixtaina, V. Y., Tom’as, M. C., \& Nolasco, S. M. (2013). Moisture-dependent engineering properties of chia (Salvia hisp'anica L.) seeds. Food Chemistry, 381-397.

Gupta, R., \& Das, S. (1997). Physical properties of Sunflower seeds. Journal of Agricultural Engineering, 66, 1-8. https://doi.org/10.1006/jaer.1996.0111

Haripriya, A., \& Aparna, N. (2018). Effect of roasting on selected nutrient profile and functional properties of chia seeds ( Salvia hispanica ) and optimization of chia seed based instant soup mix. International Journal of Food Science and Nutrition, 3(2), 200-206.

Herna'ndez-Ledesma, B., Contreras, M. del M., \& Recio, I. (2011). Antihypertensive peptides: Production, bioavailability and incorporation into foods. Advances in Colloid and Interface Science, 165, 23-35. https://doi.org/10.1016/j.cis.2010.11.001

Ixtaina, V.Y, Nolasco, S., \& Tomàs, M. (2008). Physical properties of Chia (Salvia hispanica L.) seeds. Journal of Industrial Crops and Products, 28, 286-293. https://doi.org/10.1016/j.indcrop.2008.03.009

Jayanthy, G., \& Subramanian, S. (2014). Rosmarinic acid, a polyphenol, ameliorates hyperglycemia by regulating the key enzymes of carbohydrate metabolism in high fat diet - STZ induced experimental diabetes mellitus. Journal of Biomedicine and Preventive Nutrition, 4(3), 431-437. https://doi.org/10.1016/j.bionut.2014.03.006

Joshi, M., Adhikari, B., Aldred, P., Panozzo, J., \& Kasapis, S. (2011). Physicochemical and functional properties of lentil protein isolates prepared by different drying methods. Journal of Food Chemistry, 129(4), 1513-1522. https://doi.org/10.1016/j.foodchem.2011.05.131

Kachru, R., Gupta, R., \& Alam, A. (1994). Physico-chemical Constituents and Engineering Properties. Jodhpur, India.: Scientific Publishers.

Kaiser, C., \& Ernst, M. (2016). Chia. Center for Diversification Crop Profile. KY, USA.

Khattab, R., \& Arntfield, S. (2009). Functional properties of raw and processed canola meal. LWT - Food Science and Technology, 42, 1119-1124. https://doi.org/10.1016/j.lwt.2009.02.009

Kouakou, B., Marie, N., Halbin, K., Tagro, G., Florent, N., \& Dago, G. (2013). Biochemical Characterization and Functional Properties of Weaning Food Made from Cereals (Millet, Maize) and Legumes (Beans, Soybeans. J Food Chem Nutr, 1(1), 22-32.

Magdalena, L., Yanet, V., Alejandra, M., Maria, R., Sánchez, T., Ricardo, J., ... Cristina, M. (2015). Chia seed oil-in-water emulsions as potential delivery systems of $\mathrm{x}-3$ fatty acids. JOURNAL OF FOOD ENGINEERING, 162, 48-55. https://doi.org/10.1016/j.jfoodeng.2015.04.005

Marineli, R. da S., Lenquiste, S. A., Moraes, E. A., \& Jr., M. R. M. (2015). Antioxidant potential of dietary chia seed and oil (Salvia hispanica L.) in diet-induced obese rats. Food Research International.

https://doi.org/10.1016/j.foodres.2015.07.039 
Marineli, S., Aguiar, É., Alves, S., Teixeira, A., Nogueira, M., Roberto, M., \& Jr, M. (2014). LWT - Food Science and Technology Chemical characterization and antioxidant potential of Chilean chia seeds and oil ( Salvia hispanica L .). LWT - Food Science and Technology, 59(2), 1304-1310.

https://doi.org/10.1016/j.lwt.2014.04.014

McClements, D. (1999). Food emulsions: Principles, practice, and techniques (B. Raton \& FL, Eds.). CRC Press.

Mhinzi, G., \& Mrosso, H. D. (1995). Studies on Tanzania Acacia gum exudates from the series Vulgares and Gummiferae. Food Chemistry, 54, 261-264. https://doi.org/10.1016/0308-8146(95)00038-K

Montoya-Rodri'guez, A., Go'mez-Favela, M., Reyes-Moreno, C., Milán-Carrillo, J., \& Mejı'a, E. G. de. (2015). Identification of bioactive peptide sequences from amaranth (Amaranthus hypochondriacus) seed proteins and their potential role in the prevention of chronic diseases. Comprehensive Reviews in Food Science and Food Safety, 14, 139-158. https://doi.org/10.1111/1541-4337.12125

Munoz, L., Cobos, A., Diaz, O., \& Aguilera, J. (2013). Chia seed (Salvia hispanica): an ancient grain and a new functional food. Food Rev. Int, 29, 394-408. https://doi.org/10.1080/87559129.2013.818014

Muñoz, L. A., Cobos, A., Diaz, O., \& Aguilera, J. M. (2012). Chia seeds : Microstructure, mucilage extraction and hydration. 108, 216-224. https://doi.org/10.1016/j.jfoodeng.2011.06.037

Nieman, D.C, Gillitti, N., Jin, F., Henson, D., Kennerly, K., Shanely, R., ... Schwartz, S. (2012). Chia seed supplementation and disease risk factors in overweight women: a metabolomics investigation. . J Altern Complement Med, 18, 700-708. https://doi.org/10.1089/acm.2011.0443

Nieman, David C, Cayea, E. J., Austin, M. D., Henson, D. A., Mcanulty, S. R., \& Jin, F. (2009). Chia seed does not promote weight loss or alter disease risk factors in overweight adults. Nutrition Research, 29(6), 414-418. https://doi.org/10.1016/j.nutres.2009.05.011

Oliveira-Alves, C., Vendramini-Costa, D., Cazarin, C. B., J'unior, M. M., Ferreira, J. B., Silva, A., \& Bronze, M. (2017). Characterization of phenolic compounds in chia (Salvia hispanica L.) seeds, fiber flour and oil. Journal of Food Chemistry, 232, 295-305. https://doi.org/10.1016/j.foodchem.2017.04.002

Olivos-Lugo, B., Valdivia-López, M., \& Tecante, A. (2010). Thermal and physicochemical properties and nutritional value of the protein fraction of Mexican chia seed (Salvia hispanica L. Food Science and Technology International, 16(1), 89-96. https://doi.org/10.1177/1082013209353087

Orona-Tamayo, D., Valverde, M. E., \& Pez, O. P.-L. (2016). Chia-The New Golden Seed for the 21st Century: Nutraceutical Properties and Technological Uses. https://doi.org/10.1016/B978-0-12-802778-3.00017-2

Pallaro, A., Feliu, M., Vidueiros, S., Slobodiank, N., Ayerza, R., Coates, W., \& Fernandez, I. (2004). Estudio de la calidad proteica de una fuente no tradicional. Resumenes del Congreso Internacional de Ciencia y Tecnologia de los Alimentos. Cordoba, Argentina.

Peiretti, P., \& Gai, F. (2009). Fatty acid and nutritive quality of Chia (Salvia hispanica L.) seeds and plant during growth. Journal of Aanimal Feed Science Technology, 148, 267-275. https://doi.org/10.1016/j.anifeedsci.2008.04.006

Peperkamp, M. (2015). CBI Tailored Intelligence: chia from Bolivia 'a modern super seed in a classic pork cycle. The Hague, Netherlands.

Pez, G. L., Ros, G., N, F. R., Periago, M., Martı'nez, M., \& J. Ortuñ o. (1997). Propiedades funcionales de la fibra diete' tica. Mecanismo de acción en el tracto gastrointestinal. Archivos Latinoamericanos de Nutricio'n, 47(3), 203-207.

Reyes-Caudillo, E., Tecante, A., \& Valdivia-Ló́pez, M. (2008a). Dietary fiber and antioxidant activity of phenolic compounds present in Mexican Chia (Salvia hispanica L.) seeds. Journal of Food Chemistry, 107, 656-663. https://doi.org/10.1016/j.foodchem.2007.08.062

Reyes-Caudillo, E., Tecante, A., \& Valdivia-Lo'pez, M. A. (2008b). Dietary fibre content and antioxidant activity of phenolic compounds present in Mexican chia ( Salvia hispanica L .) seeds. Food Chemistry, 107, 656-663. https://doi.org/10.1016/j.foodchem.2007.08.062

Rocha, J., Eduardo-Figueira, M., Andreia, B., Adelaide, F., Dora, B., Rosario, B., ... Bruno, S. (2015). Anti inflammatory Effect of Rosmarinic Acid and an Extract of Rosmarinus officinalis in Rat Models of Local and Systemic Inflammation. Basic \& Clinical Pharmacology \& Toxicology, 116, 398-413.

https://doi.org/10.1111/bcpt.12335 
Rodri'guez, P., Pérez, E., Romel, G.,\& Dufour, D. (2011). Characterization of the proteins fractions extracted from leaves of Amaranthus dubius (Amaranthus spp.). African Journal of Food Science, 5, 417-424.

Rosales-Mendoza, S., Paz-Maldonado, L. M., Govea-Alonso, D., \& Korban, S. (2013). Engineering production of antihypertensive peptides in plants. Plant Cell, Tissue and Organ Culture, 112, 159-169.

https://doi.org/10.1007/s11240-012-0231-9

Rulfo, J. (1937). La chia. Agricultura, 1, 28-37.

Salgado-Cruz, M., Calderón-Domínguez, G., Chanona-Pérez, J., Farrera-Rebollo, R., Méndez-Méndez, J., \& Díaz-Ramíreza, M. (2013). Chia (Salvia hispanica L.) seed mucilage release characterisation. A microstructural and image analysis study. Journal of Industrial Crops Products, 51, 453-462. https://doi.org/10.1016/j.indcrop.2013.09.036

Sandoval-Oliveros, M., \& Paredes-López, O. (2013). Isolation and characterization of proteins from Chia seeds (Salvia hispanica L.). Journal of Agriculture and Food Chemistry, 61, 193-201. https://doi.org/10.1021/jf3034978

Sapio, O. Di, Bueno, M., Busilacchi, H., \& Severin, C. (2008). Chía: importante antioxidante vegetal. Agromensajes de La Facultad, 56, 11-13.

Segura-campos, M. R., Salazar-vega, I. M., Chel-guerrero, L. A., \& Betancur-ancona, D. A. (2013). LWT - Food Science and Technology Biological potential of chia ( Salvia hispanica L .) protein hydrolysates and their incorporation into functional foods. LWT - Food Science and Technology, 50(2), 723-731. https://doi.org/10.1016/j.lwt.2012.07.017

Shevkani, K., Singh, N., Kaur, A., \& Rana, J. (2015). Structural and functional characterization of kidney bean and field pea protein isolates: a comparative study. Food Hydrocolloids Journal, 43, 679-689. https://doi.org/10.1016/j.foodhyd.2014.07.024

Silva, B. da, Anunciac, ao, P. C., Matyelka, J., C. M. da. S., Lucia,C. M. D.,Martino, H. S. D., Pinheiro-Sant'Ana, H. M. (2017). Chemical composition of Brazilian chia seeds grown in different places. Journal of Food Chemistry, 221, 1709-1716. https://doi.org/10.1016/j.foodchem.2016.10.115

Souza, F. De, Souza, F. L. de, Santo, S. E. G., \& Rosa, G. (2015). Effect of chia seed (Salvia hispanica L.) consumption on cardiovascular. Journal of Nutrición Hospitalaria, 32, 1909-1918.

Spotorno, V., Mateo, C. M., Ixtaina, V. Y., Mart, M. L., Diehl, B. W. K., Nolasco, S. M., \& Toma, M. C. (2011). Journal of Food Composition and Analysis Characterization of chia seed oils obtained by pressing and solvent extraction. 24, 166-174. https://doi.org/10.1016/j.jfca.2010.08.006

Srichuwong, S., Curti, D., Austin, S., King, R., Lamothe, L., \& Gloria-Hernandez, H. (2017). Physicochemical properties and starch digestibility of whole grain sorghums, millet, quinoa and amaranth flours, as affected by starch and non-starch constituents. Journal of Food Chemistry, 233, 1-10.

https://doi.org/10.1016/j.foodchem.2017.04.019

Suri, S., Passi, S., \& Goyat, J. (2016). Chia Seed ( Salvia Hispanica L.) - a New Age Functional Food. 4th International Conference on Recent Innovations in Science Engineering and Management, 286-299. New Delhi: India International Centre.

Taylor, P., Vázquez-ovando, A., Betancur-ancona, D., \& Chel-guerrero, L. (2012). Physicochemical and functional properties of a protein-rich fraction produced by dry fractionation of chia seeds ( Salvia hispanica L.). (November 2013), 37-41. https://doi.org/10.1080/19476337.2012.692123

Tello, E. N. (2014). Efecto de la fecha de siembra sobre el crecimiento y rendimiento de chía blanca (Salvia hispanica L.) establecida en la localidad de las cruces provincia de San Antonio. Universidad de Chile. Santiago de Chile.

Toscano, L. T., \& Surama, C. (2014). Chia Flour Supplementation Reduces Blood Pressure in Hypertensive Subjects. 392-398. https://doi.org/10.1007/s11130-014-0452-7

Tunde-Akintunde, T., \& Akintunde, B. (2004). Some physical properties of Sesame seed. Biosyst. Eng, 88, 127-129. https://doi.org/10.1016/j.biosystemseng.2004.01.009

Ullah, R., Nadeem, M., Khalique, A., Imran, M., Mehmood, S., \& Javid, A. (2016). Nutritional and therapeutic perspectives of Chia ( Salvia hispanica L.): a review. Journal of Food Science and Technology, 53(April), 1750-1758. https://doi.org/10.1007/s13197-015-1967-0 
USDA. (2004). Seeds, chia seeds, dried. Nutrient Database for Standard Reference.

Valdivia-lópez, M. Á., \& Tecante, A. (2015). Chia ( Salvia hispanica ): A Review of Native Mexican Seed and its Nutritional and Functional Properties. In Advances in Food and Nutrition Research (1st ed., Vol. 75). https://doi.org/10.1016/bs.afnr.2015.06.002

Vannice, G., \& Rasmussen, H. (2014). Position of the academy of nutrition and dietetics: Dietary fatty acids for healthy adults. J. Acad. Nutr. Diet, 114, 136-153. https://doi.org/10.1016/j.jand.2013.11.001

Vázquez-ovando, A., Betancur-ancona, D., Chel-guerrero, L., Betancur-ancona, D., \& Chel-guerrero, L. (2013). Physicochemical and functional properties of a protein-rich fraction produced by dry fractionation of chia seeds ( Salvia hispanica L .). 6337. https://doi.org/10.1080/19476337.2012.692123

Velasco, L., \& Fernandez-Martinez, J. (2002). Breeding oilseed crops for improved oil quality. Journal of Crop Production, 5(1-2), 309-344. https://doi.org/10.1300/J144v05n01_13

Vilche, C., Gely, M., \& Santalla, E. (2003). Physical properties of quinoa seeds. Biosyst. Eng, 86, 59-65. https://doi.org/10.1016/S1537-5110(03)00114-4

Vuksan, V., Choleva, L., Jovanovski, E., Jenkins, A. L., Dias, A. G., Ho, H. V. T., ... Duvnjak, L. (2016). Comparison of fl ax ( Linum usitatissimum ) and Salba-chia (Salvia hispanica L .) seeds on postprandial glycemia and satiety in healthy individuals : a randomized, controlled, crossover study. (May), 1-5. https://doi.org/10.1038/ejen.2016.148

Vuksan, V., Jenkins, A. L., Brissette, C., Choleva, L., \& Jovanovski, E. (2017). Nutrition, Metabolism \& Cardiovascular Diseases Salba-chia (Salvia hispanica L .) in the treatment of overweight and obese patients with type 2 diabetes : A double-blind randomized controlled trial. 138-146. https://doi.org/10.1016/j.numecd.2016.11.124

Vuksan, V., Whitham, D., Sievenpiper, J., Jenkins, A., Rogovik, A., Bazinet, R., ... Hanna, A. (2007). Supplementation of conventional therapy with the novel grain salba (Salvia hispanica L.) improves major and emerging cardiovascular risk factors in type 2 diabetes. Diabetes Care, 30, 2804-2810. https://doi.org/10.2337/dc07-1144

Weber, W., Gentry, S., Kolhepp, A., \& McCrohan, R. (1991). The nutritional and chemical evaluation of chia seeds. Journal of Ecology of Food Nutrition, 26, 119-125. https://doi.org/10.1080/03670244.1991.9991195

Zettel, V., \& Hitzmann, B. (2018). Applications of chia (Salvia hispanica L.) in food products. Trends in Food Science \& Technology, 1-48. https://doi.org/10.1016/j.tifs.2018.07.011

\section{Copyrights}

Copyright for this article is retained by the author(s), with first publication rights granted to the journal.

This is an open-access article distributed under the terms and conditions of the Creative Commons Attribution license (http://creativecommons.org/licenses/by/4.0/). 